\title{
Emerging Stereotypes about the Target Culture through Popular Culture and Cultural Heritage References in EFL Textbooks
}

\author{
María Daniela Cifone Ponte $^{1} \&$ Andrés Canga Alonso ${ }^{1}$ \\ ${ }^{1}$ Universidad de La Rioja, La Rioja, Spain \\ Correspondence: María Daniela Cifone Ponte, Calle San José de Calasanz, 33, Universidad de La Rioja, Edificio de \\ Filologías, Departamento de filologías modernas. Despacho 106, 26004, Logroño, La Rioja, Spain.
}

Received: March 17, 2021

doi:10.5430/wjel.v11n1p43

\begin{abstract}
EFL textbooks are not only grammar references but also a tool through which learners get their first glimpses to the target culture. Thus, their content should be carefully selected to avoid providing the learners with a conventionalized view of the target society which is likely to contribute to create cultural stereotypes. This paper analyzes references to the target culture through the examination of two cultural categories: Popular Culture and Cultural Heritage in five $2^{\text {nd }}$ Baccalaureate EFL textbooks used in La Rioja, Spain. The main purpose of the present study is to explore (i) the status of the target culture over other cultures in these materials and, (ii) the gender, nationality and ethnic stereotypes that may emerge from their content. Results evince that the target culture is predominant in EFL textbooks used by $2^{\text {nd }}$ Baccalaureate students and stereotypes related to gender, ethnicity and nationalities are strongly present in their content.
\end{abstract}

Keywords: target culture, EFL textbooks, EFL stereotypes, popular culture, cultural heritage

\section{Introduction}

Learning a new language means not only being in contact with linguistic aspects but also with the cultural framework in which this language develops (Alptekin, 2002). In this regard, it is important to consider that the process of becoming familiar with a new language implies encountering a wide range of cultural aspects which may be unknown and full of new associations which "reflect a multifaceted reality, implied meanings and symbols" (Nizegorodcew, 2011, p. 9). In fact, foreign language learners are in contact with different ideas, values and beliefs associated with the target culture (Nizegorodcew, 2011). In recent decades, English has suffered a global spread. Consequently, intercultural competence emerged as a response to the need of a successful communication among speakers with different cultural backgrounds (Byram, 2011). This notion seems to be vital in English as a foreign language (EFL) teaching context since English is being used for international communication by speakers who do not only communicate with native English speaker but with people from different cultural backgrounds (Byram, 2011).

These views have provoked a surge in research related to students' exposure to culture in EFL classrooms. Recent research into the inclusion of intercultural competence in EFL materials suggests that the target culture is mostly represented in regard with their cultural content. Despite the undeniable benefits purported by the target culture in EFL contexts (Alptekin, 1993; Méndez García, 2005), caution should be taken since scholars have reported that EFL materials offer a conventionalized view of the target society that may contribute to the creation of stereotypes (Ndura, 2004). Thus, the question of what constitutes a balanced representation of the target culture within EFL materials research seems to be relevant for research.

The goal of this paper is to examine the representation of the target culture in five EFL textbooks used in La Rioja, Spain. Two cultural categories (i.e. popular culture and cultural heritage) which may be relevant for the analysis of the target culture under the notions of nationalities, gender and ethnicity were selected according to the sociolinguistic specifications made in the curriculum of this Autonomous Community (Decree 21/2015). Thus, this study broadens new perspectives regarding the representation of the target culture in EFL textbooks as: (i) it examines its predominance in the materials through two cultural categories: popular culture and cultural heritage, (ii) it classifies references about the target culture as for nationalities from the inner circle, gender and ethnicity and, (iii) it defines how the selection of these references may contribute to the creation of stereotypes related to the target culture. 
The paper is divided into six sections. Section one serves as an introduction to the paper. Section 2 provides the reader with an overview of the main tendencies of intercultural competence in EFL materials, and previous studies on stereotypes in EFL textbooks. Section 3 describes the sample and the method used to analyze the cultural references. In Section 4, we report the main results. Section 5 deals with the discussion of the results. Finally, section 6 reveals the main conclusions and implications of this study for EFL teaching and learning.

\section{Literature Review}

\subsection{Culture and EFL Materials}

It is widely accepted that there is a tendency to have a bigger representation of the target culture in the vast majority of internationally produced EFL textbooks (Lee, 2009; Canga Alonso \& Cifone Ponte, 2015). According to Alptekin (1993), this is an extended practice as: (i) it is cheaper to produce one edition of a series of textbooks globally; (ii) authors of these materials are usually English native speakers who, unconsciously, reflect their own reality in their content; (iii) historically, there has been a tendency of emphasizing the target language culture over the rest of cultures. In this regard, Méndez García (2005) emphasized the students' need of familiarizing with some of the most relevant characteristics and behaviours of the target society since being in contact with the target language will be beneficial as it promotes a sense of empathy and respect, helps create reflexive knowledge about students' own culture and fosters intercultural communication. Nevertheless, the representation of the target culture in EFL is said to be unrealistic as it supports an artificial, prototypical and limited view of this culture. Although scholars claim that students should be in contact with different varieties, accent and customs and behaviours as English is becoming a 'world language', the underlying approach within EFL textbooks is usually limited to American and British cultures as the main representation of the target culture (Matsuda, 2002; Wandel, 2002; Setyono \& Widodo, 2019; Canga Alonso \& Cifone Ponte, 2021).

High culture (Big C culture) and low culture (small c culture) (Halverson; 1985) need to be reviewed in this section since they are of utmost relevance for the present study. High culture refers to aspects of culture related to the most intellectual side of our society and has an aesthetic component (e.g. art and literature) (Halverson, 1985; Scruton, 2012). Low culture involves elements of popular culture and it is commonly associated with a less educated group or with young people (Cheung, 2001). The presence of these two different types of culture in EFL instruction has changed over the years. In fact, EFL textbooks were filled with high culture references until 1950s (Ulrich, 2004). In the coming decades, the communicative revolution took place and transformed the instruction and the learning process of a language. Nowadays, EFL learners are required to communicate in every-day situations. Hence, topics related to everyday situations acquired greater relevance in EFL classrooms and, therefore, in EFL materials (Cheung, 2001). Given the power culture may have for enhancing motivation in students, it should be regarded as an opportunity within the classroom. The introduction of elements from pop culture which may be easily recognized by young and teenage learners may awake their interest and they may start to identify themselves with the language they are learning (Furlong \& Maynard, 1995; King, 2002; Rabbani, 2015).

Scholars consider both types of cultures of great importance for the development of intercultural competence in EFL classrooms. In this regard, different authors have built lists of cultural categories where both aspects are emphasized (Byram \& Morgan, 1994; Risager, 1991). Moreover, the Common European Framework of Reference for Languages (CEFR) (Council of Europe, 2001; 2018) also offers a list of cultural categories which are claimed to be essential to foster students' sociolinguistic competence. In this document, relevant features of cultures are represented by means of categories (e.g. everyday living, social conventions and values, beliefs and attitudes). It also makes explicit reference to elements from popular culture (e.g. music, visual arts, popular music, discos, etc.) as an essential part of intercultural competence. In 2018, a more defined set of sociolinguistic characteristics that students need to acquire during their learning are described. Thus, students in B1 levels should be capable of recognizing some of the most well-known people, institutions, and place names from the target culture. It is not determined, however, if they should recognize historical, literary figures or celebrities (Council of Europe, 2018).

In this vein, in the Spanish context, sociocultural aspects are established in the EFL curricula. In particular, the importance within the instruction of vocabulary is emphasized in the curriculum of Secondary Education from La Rioja (Decree 21/2015). Explicit mention to the target culture is made to cultural aspects from the target culture; these aspects are closely related to the inclusion of both high culture and popular culture. Moreover, the need of exposing students to relevant sociocultural information to overcome stereotypes is also emphasized.

\subsection{Stereotypes in EFL Materials}

Textbooks are not only a grammar reference, but they are a window towards the culture of a given language. In fact, 
not only the content but the linguistic and lexical choices can affect students' attitudes, perceptions and motivation to learn the language (Lee \& Mahmoudi-Gahrouei, 2020). In this vein, EFL textbooks should be inclusive and embrace diversity in order to foster intercultural competence. However, their content choices are not usually made considering these premises. In other words, textbooks content seems to be rigid and culturally biased (Ndura, 2004). These views may be facilitating the creation of stereotypes (Ndura, 2004; Lee \& Mahmoudi-Gahrouei, 2020).

Stereotypes are often concerned with a conventionalized representation of other cultures' thoughts, behaviours and people. In fact, Hall (1997) believed that stereotypes take place when the cultural representations are limited to the description of basic characteristics such as gender, nationality and skin colour. As for EFL textbooks, previous studies have revealed that the stereotyped view students received is strongly related to gender and ethnicity (Otlowski, 2003; Arikan, 2005; Foroutan, 2012; Hilliard, 2014; Lee \& Chin, 2019). Women's image in textbooks has long been examined; numerous studies suggest that female representation is weak in opposition to males (Arikan, 2005; Foroutan, 2012, Lee \& Chin, 2019). Arikan (2005) pointed at a lack of balance in the distribution of genders in visuals within EFL textbooks. On the other hand, racial bias in EFL textbooks also points to lack of diversity (Otlowski, 2003; Hilliard, 2014). Otlowski (2003) showed that the visual content of EFL textbook only represented white upper-class people while minorities were completely excluded. This scholar claims that this representation is unreal as American and British society is characterized by a great variety of ethnic backgrounds (Otlowski, 2003). Similarly, Hilliard (2014) also revealed that ethnicity in EFL materials is dominated by references to Caucasian characters while others such as Asian, Latino or Black/ African American are being neglected.

In regard with the representation of famous people in EFL textbooks, Babaii, Atai and Parsazadeh (2019) conducted a study on different series of textbooks by international publishing houses. Their analysis showed a tendency in the representation of celebrities and famous personages in EFL textbooks. Overall, they found that most visual references referred to celebrities in the field of media (Babaii, Atai \& Parsazadeh, 2019). In fact, they refer to the field of media as the most superficial layer of culture while references to people from the field of sciences, arts or politics are overlooked (Babaii, Atai \& Parsazadeh, 2019). These scholars also noticed that EFL textbooks are inclined to include people from the inner circle in their images (Babaii, Atai \& Parsazadeh, 2019). Despite their aim was to explore the visual content of EFL materials, these results are of interest for our study as they support that popular culture from the target culture predominates in EFL materials. However, further analysis on how these references may affect the creation of stereotypes is needed.

Despite the cultural aspects related to both: high and low culture are considered essential by the Spanish curriculum, to our knowledge, studies on the target cultures' stereotypes through the inclusion of popular culture and cultural heritage elements in Spain are scarce. Thus, the present study aims to find answers to the following research questions:

RQ1. What is the status of the target culture within second baccalaureate textbooks through popular culture and cultural heritage references?

RQR. What are the emerging stereotypes associated to the target culture derived from the inclusion of references to popular culture and cultural heritage in EFL textbooks?

\section{Methodology}

\subsection{Sample}

In the current study, five EFL textbooks were selected. They are used in five high schools in La Rioja, Spain. Two of the textbooks (Top Marks and Upgrade) are published by national publishing houses while the other three materials (Over to you, Distinction and Move on) are compiled by an international publishing house. The selection of these materials was done according to the following criteria: (i) these high schools were part of a longitudinal research project where the receptive and lexical competence of their students was assessed, (ii) the five materials were specifically designed for 2nd of Baccalaureate, so they should follow the Spanish curricula.

\subsection{Data Analysis}

To analyze the presence of the target culture in our sample and the potential stereotypes encoded in this content we have adopted the following methodological decisions. The selection of cultural references was done following the recommendations of CEFR (Council of Europe, 2001; 2018) and Byram and Morgan's (1994) list of cultural categories. The CEFR list promotes the inclusion of historical characters, literature, and events as part of the cultural component in EFL instruction. These aspects will be considered in the cultural heritage category. Similarly, Byram and Morgan's (1994) list proposes the inclusion of aspects related to music, TV and media which will be encompassed by the category of popular culture. In order to define stereotypes emerging from the previous 
classification, Yuen's (2011, p. 462) criterion for the categorization of references to foreign cultures was followed and allowed us to classify the elements by 'products' (e.g. films or books) and 'persons' (e.g. celebrities or historical personages). As for stereotypes, we have focused on common cultural stereotypes: gender (Arikan, 2005), ethnicity and nationality (Hilliard, 2014). To examine ethnicity, we have relied on Hilliard's classification of the concept: Caucasian, Asian, Lation, Black/American and Others. Nationalities were classified in terms of countries from the inner circle (Kachru, 1992).

Data management and analysis were performed using Microsoft Excel and WordSmith. The process of classification of cultural references consisted of three steps: (i) the content of the coursebooks were examined; (ii) references which followed the abovementioned criteria were written down in a Microsoft Excel file; (iii) they were later processed with WordSmith to obtain two lists (one by category) per textbook. As our analysis was qualitative, we did not consider the frequency of each reference.

The analysis of each list allowed us to classify each reference as a 'product' or 'person' (Yuen, 2011) and to determine the culture they were referring to (i.e., target, source or international). This analysis was done manually to determine the level of representation of the target culture in each category and coursebook. Finally, stereotypical constructions encoded in the references of the target culture were classified according to ethnicity, gender and nationality.

\section{Results}

The purpose of the first research questions was to ascertain what culture is predominant in EFL textbooks. To be more specific, we sought to describe the status of the target culture in two categories (i.e., popular culture and cultural heritage). From the analysis of the sample, we obtained a corpus of 252 cultural references; 156 elements from popular culture, and 96 types from cultural heritage (see table 1).

Table 1. Representation in percentage of Popular Culture and Cultural Heritage of the target culture

\begin{tabular}{lcccccc}
\hline \multirow{2}{*}{ Textbooks } & \multicolumn{3}{c}{ Popular Culture } & \multicolumn{3}{c}{ Cultural Heritage } \\
\cline { 2 - 7 } & $\begin{array}{c}\text { Cultural } \\
\text { references }\end{array}$ & $\begin{array}{c}\text { Target } \\
\text { culture }\end{array}$ & $\%$ & $\begin{array}{c}\text { Cultural } \\
\text { references }\end{array}$ & Target culture & $\%$ \\
\hline Top Marks & 25 & 16 & $64 \%$ & 12 & 7 & $58.33 \%$ \\
Upgrade & 18 & 14 & $77.78 \%$ & 15 & 8 & $53.33 \%$ \\
Over to you & 20 & 14 & $70 \%$ & 24 & 12 & $50 \%$ \\
Move On & 66 & 38 & $57.58 \%$ & 40 & 17 & $42.5 \%$ \\
Distinction & 27 & 21 & $77.78 \%$ & 5 & 3 & $60 \%$ \\
\hline
\end{tabular}

As illustrated in Table 1, our data revealed the great relevance provided to the target culture in EFL materials by means of the two categories. This means that international and the source cultures are being overlooked. Although this seems to be a tendency in both categories, we ascertained the presence of more elements belonging popular culture from the target culture. The only exception was found in Over to you, where both categories seem to be balanced.

Regarding the representation of inner circle countries, we found that there is inclusion of both: American and British products and people in popular culture; being American references extensively represented in most textbooks (e.g. Matt Damon, The Simpsons). Regarding other cultures within the inner circle (e.g. Australian, Scottish, Canadian, etc.), our data showed that these countries were undervalued, although some references to Irish, Canadian and Welsh cultures were described. In this regard, the tendency revealed by cultural heritage references was the opposite. British references within products and people were widely included (e.g. Pride and Prejudice). However, this category showed an overall exclusion of America and other countries from the Inner Circle (see Table 2). 
Table 2. Nationality of Products and People in Popular Culture and Cultural Heritage

\begin{tabular}{|c|c|c|c|c|}
\hline & \multicolumn{2}{|c|}{ Popular Culture } & \multicolumn{2}{|c|}{ Cultural Heritage } \\
\hline & Products & People & Products & People \\
\hline \multirow[t]{4}{*}{ Top Marks } & British (1) & British (4) & British (3) & British (3) \\
\hline & American (4) & American (5) & American (1) & \\
\hline & & Australian (1) & & \\
\hline & & Canadian (1) & & \\
\hline \multirow[t]{4}{*}{ Upgrade } & British (4) & British (3) & British (3) & British (1) \\
\hline & & Irish (1) & & Irish (1) \\
\hline & & American (5) & & American (3) \\
\hline & & Welsh (1) & & \\
\hline \multirow[t]{3}{*}{ Over to you } & British (2) & British (4) & British (3) & British (4) \\
\hline & Irish (1) & American (3) & & American (5) \\
\hline & American (4) & & & \\
\hline \multirow[t]{3}{*}{ Move on } & British (10) & UK (7) & British (5) & British (6) \\
\hline & American (12) & Irish (1) & American (3) & American (3) \\
\hline & & American (7) & & \\
\hline \multirow[t]{3}{*}{ Distinction } & British (8) & UK (6) & British (3) & - \\
\hline & Irish (2) & Irish (1) & & \\
\hline & American (1) & American (3) & & \\
\hline
\end{tabular}

The second research question aimed to analyze the construction of stereotypes within the two cultural categories (i.e., popular culture and cultural heritage). As displayed in Table 3, when it comes to gender, popular culture mostly referred to a white male perspective (e.g. Jamie Oliver). Other ethnicities were neglected, and the presence of women is scarce. However, most references encountered described a white woman (e.g. Geri Halliwell). Similarly, cultural heritage was also dominated by a white male perspective (e.g. Abraham Lincoln). However, our data revealed that the differences in gender bias were noticeable in this category as women were excluded from the content (Table 3) Although there were also some glimpses to black males (e.g. Barack Obama), references to other races apart from white were rare.

Table 3. Gender and race in Popular Culture and Cultural Heritage

\begin{tabular}{lllll}
\hline \multirow{2}{*}{ Top Marks } & \multicolumn{2}{c}{ Popular Culture } & \multicolumn{2}{c}{ Cultural Heritage } \\
\cline { 2 - 5 } & \multicolumn{1}{c}{ Gender } & Race & Romen (1) & White (3) \\
\cline { 2 - 5 } Upgrade & Women (4) & White (11) & Men (2) & \\
& Women (3) & Black (1) & Men (5) & Black (1) \\
& Men (7) & White (8) & & White (4) \\
Over to you & Women (3) & Asian (1) & Men (9) & Black (1) \\
& Men (4) & White (6) & & White (8) \\
Move on & Women (5) & Black (6) & Women (1) & White (9) \\
& Men (11) & White (13) & Men (8) & \\
Distinction & Women (6) & Black (1) & & - \\
& Men (4) & White (9) & & - \\
\hline
\end{tabular}

\section{Discussion}

The first research question aimed to define the status of the target culture in EFL textbooks by means of two cultural categories (i.e. popular culture and cultural heritage). Our results revealed that the content of those categories is driven by a monocultural perspective. In broad strokes, the data obtained from comparing the three types of culture (target, source and international) let us claim that the target culture prevails the references to people and products in EFL textbooks. This finding concurs with earlier observations which showed that the target culture holds a privileged status within EFL materials (Alptekin, 1993; Lee, 2009; Canga Alonso \& Cifone Ponte, 2015). In this regard, previous studies found that celebrities and famous people from the target culture have more representation than famous characters from other cultures (Lee, 2009; Babaii, Atai \& Parsazadeh, 2019). Our results also confirmed that historical personalities from the target culture have a main role in EFL materials in comparison to references to other 
cultures; this corroborates Lee's (2009) assertion that historical references in EFL materials are focused on the target culture and they are normally represented with admiration.

Regarding the representation of inner circle countries within the two categories, there is a tendency to overrepresent American and British cultures. Despite some isolated references to Irish and Canadian cultures, EFL textbooks seem to neglect other inner circle cultures as they are virtually excluded from both categories. Our results seem to indicate that American and British cultures are receiving a different treatment in EFL materials. First, there is an Americanization of popular culture in EFL instruction. This concurs with previous research on EFL textbook cultural references $(\mathrm{Su}, 2014)$. This tendency to include American popular culture references may be accounted for its worldwide popularity (Toprak \& Aksoyalp, 2015). More specifically, American popular culture products (e.g., films, TV shows) are rooted in today's society due to the influence of Hollywood in the film industry and platforms such as YouTube and Netflix (Dizon, 2018). It seems reasonable to assume that these products would be part of the textbooks addressed to adolescents as these references may be easier to be understood and recognized by teenagers (Cheung, 2001). This assumption may be explained as an attempt to promote students' sense of belonging and motivation as they can identify themselves with this content (Nizegorodcew, 2011).

We now move on to the discussion of the findings related to our second research question, in which we sought to describe the main stereotypes concerning gender, ethnicity and nationalities. In this regard, both categories followed a similar pattern. The content of EFL textbooks seem to be driven by a white male perspective. This outcome concurred with previous studies on gender bias in EFL textbooks where women have a secondary role in their visual content and in the order of appearance in the text (Arikan, 2005; Foroutan, 2012, Lee \& Chin, 2019). Diversity in terms of races is also neglected in our sample of EFL materials as most of their content is dominated by Caucasians references (Otlowski, 2003; Hilliard, 2014). As for the differences found in both categories, our data also showed that stereotypes may be built in conjunction with the gender and ethnicity choices. Popular culture reported a higher inclusion of female references than cultural heritage. The analysis of these references revealed that all these women were Caucasian. This finding seems to indicate that Spanish students are exposed to a stereotyped view of the society of the target culture where Caucasian female references from the popular culture (e.g., Keira Knightly, Lily Simons) have higher visibility than female historical characters or authors. These findings may show a parallelism with previous studies conducted on internationally published textbooks (Babaii, Atai \& Parsazadeh, 2019) since they proved a dominance of celebrities from the most superficial layer of culture. Moreover, these results may be explained on the roles assigned to women in EFL textbooks. These roles are usually associated to advertising and marketing purposes and they contribute to reflect women's position in society (Eckert \& McConnell-Ginet, 2013; Amerian \& Esmaili, 2015). Moreover, the predominance of male figures in both categories may be explained by patriarchal ideologies and roles currently rooted in some societies and shaped by mass media, traditions and customs (Gegregeorgis, 2016; Emaliana \& Tusita, 2019).

\section{Conclusion and Pedagogical Implications}

Three main findings stand out in this research. First, although students from Second Baccalaureate in Spain are exposed to a monocultural view in the content of EFL textbooks, our sample of EFL materials include, as specified in the curriculum and in the CEFR, both: elements from high and low culture. The vast majority of the cultural references concerning popular culture and cultural heritage refer to the target culture. This means that most Inner Circle cultures are being excluded from the materials. Thus, students are not being exposed to a wide perspective of the target community as EFL materials promote a view dominated by American and British cultures. In this respect, textbooks tend to Americanize popular culture whereas cultural heritage elements are more concerned to the British culture.

Our data also suggest that EFL coursebooks analyzed are fostering the creation of gender, ethnic and nationality stereotypes referring to the target culture. EFL materials emphasize the superiority of white males in the target language society. Overall, references to women are limited. However, there is a higher number of references of women from popular culture such as celebrities or models than female historical character or authors. This last aspect is strongly dominated by male figures. In this respect, EFL textbooks may be fostering stereotypical gender views as the representation of real female references is prevailed by roles exclusively related to the fashion and film industry. Sport women, female scientists, authors and historical characters are erased from the representation of the target culture in EFL materials. Finally, the representation of female characters from different races is limited to Caucasian women.

This study may have implications at different levels. As for EFL teaching, we observe students are being exposed to a limited and stereotyped view of the target society that may affect negatively on their conceptions and their 
willingness to learn. Teachers should be aware of these limitations in their content and try to broaden students' perspectives by explicitly discussing these aspects in class or by enriching the textbooks' content with the use of other resources.

We acknowledge that this study may have some limitations since we have focused our research on in-text references to people and products from popular culture and cultural heritage. Further studies should delve into other sources of information within EFL textbooks such as the images that surround these texts and the listening activities as these parts of the textbooks may have a higher inclusion of other cultures, genders or ethnic groups. Furthermore, we believe further studies should consider a wider sample of materials in different educational levels to explore the way EFL materials refer to culture within the aforementioned categories (popular culture and cultural heritage).

\section{References}

Alptekin, C. (1993). Target-language culture in EFL materials. ELT Journal, 47(2), 136-143. https://doi.org/10.1093/elt/47.2.136

Alptekin, C. (2002). Towards intercultural communicative competence in ELT. ELT journal, 56(1), 57-64. https://doi.org/10.1093/elt/56.1.57

Amerian, M., \& Esmaili, F. (2015). Language and gender: A critical discourse analysis on gender representation in a series of international ELT textbooks. International Journal of Research Studies in Education, 4(2), 3-12. https://doi.org/10.5861/ijrse.2014.963

Arikan, A. (2005). Age, gender and social class in ELT coursebooks: A Critical Study. Hacettepe University Journal of Education, 28, 29-38.

Babaii, E., Atai, M. R., \& Parsazadeh, A. (2019). A visual analysis of English language textbooks: Celebrities' role as cultural figures. Journal of English Language Teaching and Learning, 11(24), 55-78.

Byram, M. \& Morgan. C. (1994). Teaching-and-learning Language-and-culture. Clevedon: Multilingual Matters.

Byram, M. (2011). Conceptualizing intercultural (communicative) competence and intercultural citizenship. In J. Jackson (Ed.), The Routledge Handbook of Language and Intercultural Communication, (pp. 85-97). London, U.K.: Routledge.

Canga Alonso, A., \& Cifone Ponte, M. D. (2015). An analysis of cultural vocabulary in ELT textbooks. ODISEA. Revista de estudios ingleses, 16, 83-96.

Canga Alonso, A., \& Cifone Ponte, M. D. (2021). Cultural terms in EFL textbooks for young learners. Encuentro Journal, 29, 90-103.

Cheung, C. K. (2001). The use of popular culture as a stimulus to motivate secondary students' English learning in Hong Kong. ELT Journal, 55(1), 55-61. https://doi.org/10.1093/elt/55.1.55

Council of Europe. (2001). Common European framework of reference for languages: Learning, teaching, assessment. Cambridge, U.K: Press Syndicate of the University of Cambridge.

Council of Europe. (2018). Common European framework of reference for languages: Learning, teaching, assessment. Companion volume with new descriptors. Cambridge, U.K: Press Syndicate of the University of Cambridge.

Decree 21/2015, de 26 de junio, por el que se establece el currículo de la Educación Secundaria Obligatoria y se regulan determinados aspectos sobre su organización, así como la evaluación, promoción y titulación del alumnado de la Comunidad Autónoma de La Rioja. Boletín Oficial de La Rioja, 79, 12368-12730. Retrieved from https://ias1.larioja.org/boletin/Bor_Boletin_visor_Servlet?referencia=2419707-1-PDF-494584-X

Dizon, G. (2018). Netflix and L2 learning: A case study. The EuroCALL Review, 26(2), 30-40. https://doi.org/10.4995/eurocall.2018.9080

Eckert, P., \& McConnell-Ginet, S. (2013). Language and gender. Cambridge: Cambridge University Press. https://doi.org/10.1017/CBO9781139245883

Emaliana, I., \& Tusita, A. (2019). Exploring gender representation: patriarchal perspectives from EFL secondary school textbooks in Indonesia. International Journal of Research - GRANTHAALAYAH, 7(11), 146-153. https://doi.org/10.29121/granthaalayah.v7.i11.2020.345

Foroutan, Y. (2012). Gender representation in school textbooks in Iran: The place of languages. Current Sociology, 60(6), 771-787. https://doi.org/10.1177/0011392112459744 
Furlong, J., \& Maynard, T. (1995). Mentoring student teachers: The growth of professional knowledge. London: Psychology Press.

Gebregeorgis, M. Y. (2016). Gender construction through textbooks: the case of an Ethiopian Primary English textbook. Africa Education Review, 13(3-4), 119-140. https://doi.org/10.1080/18146627.2016.1224579

Hall, S. (1997). Representation: Cultural representations and signifying practices. London: SAGE Publications.

Halverson, R. J. (1985). Culture and vocabulary acquisition: A proposal. Foreign Language Annals, 18(4), 327-332. https://doi.org/10.1111/j.1944-9720.1985.tb01810.x

Hilliard, A. (2014). A critical examination of representation and culture in four English language texbooks. Language Education in Asia, 5(2), 238-252. https://doi.org/10.5746/LEiA/14/V5/I2/A06/Hilliard

Kachru, B. B. (1992). World Englishes: Approaches, issues and resources. Language teaching, 25(1), 1-14. https://doi.org/10.1017/S0261444800006583

King, J. (2002). Using DVD feature films in the EFL classroom. Computer Assisted Language Learning, 15(5), 509-523. https://doi.org/10.1076/call.15.5.509.13468

Lee, I. (2009). Situated globalization and racism: an analysis of Korean high school EFL textbooks. Language \&Literacy, 11(1), 1-14. https://doi.org/10.20360/G2F59N

Lee, J. F., \& Chin, A. C. (2019). Are females and males equitably represented? A study of early readers. Linguistics and Education, 49, 52-61. https://doi.org/10.1016/j.linged.2018.12.003

Lee, J. F., \& Mahmoudi-Gahrouei, V. (2020). Gender representation in instructional materials: a study of Iranian English language textbooks and teachers' voices. Sexuality \& Culture, 24, 1107-1127. https://doi.org/10.1007/s12119-020-09747-z

Matsuda, A. (2002). 'International Understanding' through teaching World Englishes. World Englishes, 21(3), 436-440. https://doi.org/10.1111/1467-971X.00262

Méndez García, M. (2005). International and intercultural issues in English teaching textbooks: the case of Spain. Intercultural Education, 16(1), 57-68. https://doi.org/10.1080/14636310500061831

Ndura, E. (2004). ESL and cultural bias: An analysis of elementary through high school textbooks in the Western United States of America. Language, Culture and Curriculum, 17, 143-153. https://doi.org/10.1080/07908310408666689

Nizegorodcew, A. (2011). Understanding culture through a Lingua Franca. In J. Arabski, \& A. Wojtaszek (Eds.), Aspects of culture in Second Language Acquisition and Foreign Language Learning (pp. 7-20). Berlin: Springer. https://doi.org/10.1007/978-3-642-20201-8_2

Otlowski, M. (2003). Ethnic diversity and gender bias in EFL textbooks. Asian EFL Journal, 5(2), 1-15.

Rabbani, F. (2015). The Millennial generation of popular culture in EFL classroom. Indonesian EFL journal, 1(1), 88-97. https://doi.org/10.25134/ieflj.v1i1.618

Risager, K. (2011). The cultural dimensions of language teaching and learning. Language Teaching, 44(4), 485-499. https://doi.org/10.1017/S0261444811000280

Scruton, R. (2012). High culture is being corrupted by a culture of fakes. Retrieved from https://www.theguardian.com/commentisfree/2012/dec/19/highculture-fake

Setyono, B., \& Widodo, H. P. (2019). The representation of multicultural values in the Indonesian Ministry of Education and Culture-endorsed EFL textbook: a critical discourse analysis. Intercultural Education, 30, 383-397. https://doi.org/10.1080/14675986.2019.1548102

Su, Y. C. (2014). The international status of English for intercultural understanding in Taiwan's high school EFL textbooks. Asia Pacific Journal of Education, 36(3), 390-408. https://doi.org/10.1080/02188791.2014.959469

Toprak, T., \& Aksoyalp, Y. (2015). The question of representation in EFL coursebooks: Are learners of English taught about New Zealand? International Journal of Society, Culture \& Language, 3(1), 91-104.

Ulrich, N. (2004). The cultural dimension in secondary MFL classrooms and textbook materials in the UK: an investigation into the student perspective (Unpublished $\mathrm{PhD}$ Thesis). University of Nottingham, Nottingham, U.K. 
Wandel, R. (2002). Teaching India in the EFL classroom: A cultural or an intercultural approach? Language Culture and Curriculum, 15(3), 264-272. https://doi.org/10.1080/07908310208666650

Yuen, K. M. (2011). The representation of foreign cultures in English textbooks. ELT Journal, 65(4), 458-466. https://doi.org/10.1093/elt/ccq089

\section{Copyrights}

Copyright for this article is retained by the author(s), with first publication rights granted to the journal.

This is an open-access article distributed under the terms and conditions of the Creative Commons Attribution license (http://creativecommons.org/licenses/by/4.0/). 